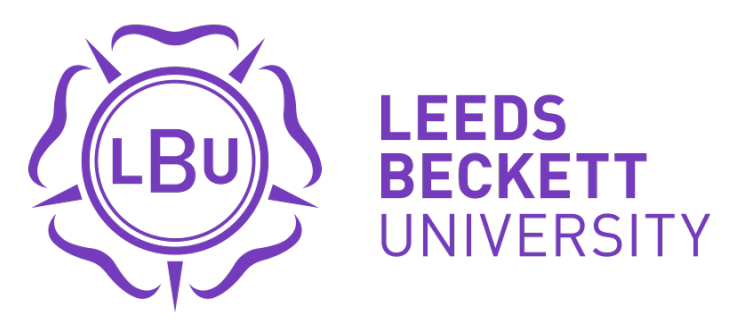

Citation:

Dart, J (2014) New Media, Professional Sport and Political Economy. Journal of Sport and Social Issues, 38 (6). 528 - 547. ISSN 0193-7235 DOI: https://doi.org/10.1177/0193723512467356

Link to Leeds Beckett Repository record:

https://eprints.leedsbeckett.ac.uk/id/eprint/258/

Document Version:

Article (Accepted Version)

The aim of the Leeds Beckett Repository is to provide open access to our research, as required by funder policies and permitted by publishers and copyright law.

The Leeds Beckett repository holds a wide range of publications, each of which has been checked for copyright and the relevant embargo period has been applied by the Research Services team.

We operate on a standard take-down policy. If you are the author or publisher of an output and you would like it removed from the repository, please contact us and we will investigate on a case-by-case basis.

Each thesis in the repository has been cleared where necessary by the author for third party copyright. If you would like a thesis to be removed from the repository or believe there is an issue with copyright, please contact us on openaccess@leedsbeckett.ac.uk and we will investigate on a case-by-case basis. 
Jon Dart

\title{
New Media, Professional Sport and Political Economy
}

\begin{abstract}
New media technologies are seen to be changing the production, delivery and consumption of professional sports and creating a new dynamic between sports fans, athletes, clubs, governing bodies and the mainstream media. However, as Bellamy and McChesney (2011) have pointed out, advances in digital technologies are taking place within social, political, and economic contexts that are strongly conditioning the course and shape of this communication revolution. This essay assesses the first wave of research on professional sport and new media technologies and concludes that early trends indicate the continuation of existing neoliberal capitalist tendencies within professional sport. Using the concept of political economy, the essay explores issues of ownership, structure, production and delivery of sport. Discussion focuses on the opportunities sports fans now have available to them and how sports organization and media corporations shifted from an initial position of uncertainty, that bordered on hostility, to one which has seen them embrace new media technologies as powerful marketing tools. The essay concludes by stating as fundamental the issues of ownership and control and advocating that greater cognizance be accorded to underlying economic structures and the enduring, all-pervasive power of neoliberal capitalism and its impact in professional sport.
\end{abstract}

\section{Keywords}

Social media, sports organizations, neoliberal capitalism, athletes, sports fans 
There is no doubt that more information is being generated now than ever before. There is no doubt also that the machinery to generate this information, to store, retrieve, process, and disseminate it, is of a quality and character never before available. The actual infrastructure of information creating, storage and dissemination is remarkable.

Herbert Schiller (1983), The communication revolution: who benefits? (p. 18)

Developments in new media technologies are seen to be changing the production, delivery and consumption of professional sports. As Hutchins and Mikosza (2010) have noted, a greater amount of sport is now being delivered to larger audiences via mobile/cell phones, laptops and tablets, digital radio, subscription and interactive television. These developments, together with the emergence of social media platforms, are changing relationships between sports fans, athletes, clubs, governing bodies and the mainstream media, with each segment seeking to capitalize on the latest technological advance. These developments have amplified tensions over the control of, and access to, the sporting products (principally, but not exclusively, live sports events). Professional sports organization and media corporations have increasingly sought to integrate new media technologies and develop their presence on across various web based platforms; the intention being to attract sports fans to come to their site, view their content, engage in "conversation" and ultimately increase their profits. Sport fans themselves have sought to take advantage of new media technologies to engage with each other and, bypassing traditional media structures, participate in less mediated and hierarchical online debates about their favourite sports, teams and athletes. Some 30 years ago Toffler (1980) claimed we were atop the crest of a technological wave and, with access to an emerging body of sports-themed research, we are now in a position to press "pause" and reflect on how new media technologies are beginning to crystallize and assess their impact within professional sport.

This essay starts from the position identified by Harvey (2005) and Bellamy and McChesney (2011), in that digital technologies have, and continue to be, developed within social, political, and economic contexts which are strongly conditioning the course and shape of the so-called "Communication Revolution." The original call for articles for this special edition asked potential authors to consider the "social, cultural and political significance resulting from the changing sports landscape"; this essay will explore how underpinning the "social, cultural, and political" landscape of professional sport is the economic. The suggestion will be made that greater cognizance be given to the underlying neoliberal structures and the profit motive. By employing a neo-Marxist interpretation of political economy a systemic assessment is made of the production, distribution and consumption of resources involved in professional sport and how monetization of the sporting product is central to the use of new media technologies. As Hirst and Harrison (2011) explain, employing political economy necessarily foregrounds the dominant mode of development and mode of production, which exist dialectically and impact upon each other and thus drive change in both technology and social relations. 
Beginning with newspapers, then radio, and television, the media has been a significant and constant companion in the development of professional sport with the latest stage of neoliberal capitalism adapting to, and exploiting, new media technologies to increase profits. At the outset of this essay it is necessary to briefly comment on the somewhat artificial distinction between "old" and "new" media. Despite the initial disruption caused by new media technologies, it has been quickly embraced by the old/traditional/mainstream media organizations. Similarly, after an initial hesitation that bordered on hostility, sport teams and organizations swiftly recognized the potential of new media technologies to market their sports product. Using a political economy approach, this essay will argue that new media technologies are not changing the nature of sport, but instead are making it more capitalist. Cognizant of spatial constraints, after outlining the dynamic between professional sport, the media and political economy, attention then moves to issues of ownership and structure. The essay then considers issues of control and content, and questions the rhetoric of participation, self-organization and cooperation before commenting on recent academic research on fan-orientated user-generated content. Assessment is then made of how new media technologies are being used in the world of professional sport, in particular by athletes, clubs, sports governing bodies and media corporations.

\section{Sport, the Media and Political Economy}

Among the first to explore the relationship between professional sport and the media were Lipski (1979) and Jhally (1984) who identified the emergence of a global sports/media complex. Their work was subsequently developed into a media sports cultural complex (Rowe, 2004), and mediasport (Wenner, 1998) who discussed the role of corporate capitalism and political economy in the creation and delivery of professional sport (see also Andrews, 2001; Beamish, 1982; Boyle and Haynes, 2000; Brohm, 1989; Gruneau \& Whitson, 2001; Hargreaves, 1982; Hoberman, 1984; Hoch, 1972; Maguire, 1999; McDonald, 2006; Rigauer, 1994; Stoddart, 2004; Whannel, 1992, 2008; Whitson, 1998). More recently, Hutchins and Rowe (2009) have highlighted the emergence of new media markets which focus on control of content rather than distribution channels. Professional sport has always been about the production of a commodity, typically a live sports event, which is sold at a profit. The corollary of production is consumption with sports sociologists turning their attention to the conditions under which the sporting commodities are consumed (Crawford, 2004; Giulianotti, 2002, 2005; Hughson \& Free, 2006; Nash, 2000; Parry and Malcolm, 2004; Wann, Melnick, Russell, \& Pease, 2001; Williams, 2007; Wilson \& White, 2002). Among the first to provide empirical evidence on the impact of new media on sport were Sage (1999), Knight and Greenberg (2002) and Lenski $(2000,2002)$. Their common focus was on how the emerging Internet could be used by politically inspired activists as an alternative medium to challenge established organizations and structures.

Underpinning new media technologies is the Internet and related digital communication whose origins lay in the cooperation of national governments, the industrial military complex and leading universities in the period after 1945 (Castells, 2001) . As Bellamy and McChesney (2011) note, "had the matter been left to the private sector, to the 'free market', the Internet never would have come 
into existence." For a brief period the Internet was restricted to non-commercial use (Castells, 2001; Schiller, 2007), but over a relatively short period it grew exponentially, driven by the desire for and profit. A fundamental feature within all forms of capitalism is its monopolistic tendencies, with those individuals or corporations who possess the greatest financial power (and related political power), using their size to dominate. This process of accumulation, here media convergence, has seen the largest players (Twitter, Google/YouTube, Microsoft, Intel, Amazon, eBay/PayPal, Facebook, Cisco, Apple) display voracious appetites as they compete with each other to take over potential competitors or "promising upstarts" (Bellamy \& McChesney, 2011). Law, Harvey and Kemp (2002) have identified a similar increase in convergence of ownership in the world of mediasport (through megamergers and acquisitions) and conclude that such mergers have shifted competition from between relatively independent dominant players to between vertical and horizontal integration. This is seen as reducing the potential range of sports "products" available, as well as space for public information and critical deliberation on these same products. This was evident at the turn of the century when large media companies began to take ownership of sports teams, with Ted Turner's 1976 purchase of the Atlanta Braves (MLB) being among the first. He subsequently developed professional wrestling via his cable television networks, with other media corporations also getting involved.

- Comcast-Spectacor purchased the Philadelphia Flyers/Eagles (NHL) in 1964. Also the Philadelphia 76ers (NBA) in 1996. Sold in 2011.

- News Corporation purchased the Los Angeles Dodgers (Baseball) in 1998. Sold in 2004. News Corp attempted to buy Manchester United in 1998 but was prevented by U.K. competition laws. News Corp's Australian division is still involved with the country's National Rugby League.

- Disney founded the Anaheim Ducks (NHL) in 1993. Sold in 2005. In 1996 Disney took control of the Anaheim Angels (MLB). Sold in 2003.

- Tribune Company purchased the Chicago Cubs (MLB) in 1981. Sold in 2007. - Cablevision purchased the New York's Knicks (NBA) in 1997 and New York Rangers (NHL) in 1995.

- The New York Times Company sold its interest in Fenway Sports Group (FSG) in 2011. FSG currently own the Boston Red Sox, Liverpool Football Club and a NASCAR team. They are also a significant stakeholder in New England Sports Network cable TV channel.

(Sources: Andreff, 2006; Forbes, 2012)

These purchases were often based on the idea of creating "synergy," in that if the media corporation owned the team they would retain a greater level of any media related profit. However, many of these same media companies subsequently unload their sports assets which are now being bought by those among the global super rich, with a particular favourite being European football teams.

\section{Get Online and Make Your Contribution}


At the centre of any attempt to understand how capitalism works (and by implication, professional sport) is the dialectic relationship between the forces of production (i.e., the raw materials, machines and technologies) and the relations of production (i.e., class), which together combine to form the mode of production (i.e., capitalism). In the current mode of capitalist production one can identify three stages, or levels, which demonstrate this distinction. The first layer is ownership of (or access to), a computer device. The second level is the ability to get online via an Internet connection and Internet Service Provider (ISP). ISPs are the only point of entry to the Internet and for which one has to pay. ISPs are currently operate virtual monopolies due to their securing of licences from national governments (the dominant players in the United States of America being AT\&T, Verizon and Comcast; in the United Kingdom they are BT, Virgin and Sky). The third level contains the specific social media site (e.g., Facebook, Twitter, YouTube), and while most of these platforms are free to use, ownership of the dominant social media platforms is predominantly held by multinational banks and venture capitalists (Cohen, 2008; Fuchs, 2011).

User-generated content (UGC) is the basis upon which most social media sites operate. UGC, also known as peer production, is a creative activity that involves social networking, photo-sharing, tagging and rating, blogging, microblogging, podcasting and video sharing activities which, some claim, take place outside the wider commodity, market-based system (Benkler, 2006). Many of the current leaders in new media (e.g., Facebook, Google, Twitter, YouTube) own very little in terms of physical assets in the traditional sense of capital ownership.' Despite this, as Fuchs $(2008,2011)$ has noted, they are able to generate large profits by trading in information freely created and donated by the "labour power" of the users-including sports fans. Online advertising has become normalized, as has sponsorship and media placement and while we have, arguably, become desensitized to advertising, those who job it is "to sell" recognize the real market value of tracking our online activities. It is therefore undeniable that the financial value of Facebook (and other similar social media corporations) is based on the freely donated labour of millions of its users, something Carr (2011) has termed digital sharecropping. The value of the users' labour manifests itself in the market capitalization of these corporations which significantly exceeds its current revenue streams (Levy, 2011).

In the early years of new media the challenge was how to make a profit, with many Internet startups bursting in the "dot.com bubble" of 2000. This profit-challenge was resolved with the exploitation of personal data, the development of sponsored links and online advertising with data mining activity fuelling the expansion of the Internet. Fuchs (2011) cites Dallas Smythe (1981/2006) who identified how in traditional media the advertisement model operated, "because audience power is produced, sold, purchased and consumed, it commands a price and is a commodity." New media typically allow free access to websites to attract traffic (i.e., users and their friends), which in turn boosts advertising revenue at the same time as collecting personal data on its users. This user data (e.g., tracking who your friends are, what sites you visit and what you buy), has become a valuable commodity which is sold to advertisers who use it to market personalized services and products. Social media platforms generate profit from advertising and exploiting the users' labour (i.e., the time and intellectual labour which is manifest in their posts, tweets, photos, video clips, 
etc). For Fuchs (2011), the difference between the traditional mass media model of audience commodity and that involving the Internet is that the latter sees the audience as also being the content producers.

As a consequence of increased blurring between production and consumption, online users have become both the producers and consumers (audiences), leading Toffler (1980, p. 267) to label them prosumers. By creating their own online communities it was anticipated that sports fans would be able to bypass the existing dominant, hierarchal mainstream media. However, one only has to turn on the radio or television to see how the mainstream (old) media now incorporate new media technologies to engage sports fans and get them to freely provide an increasing amount of content for their programs. In particular, it is the cell/ mobile phone which allows for instant, real-time contributions from sports fans - either orally or by tweets and texts. Given its recent, yet significant impact upon sports programming, there is a need for more empirical research, which builds on the work of Nylund (2007), and looks across the media spectrum. An interesting, yet difficult to undertake study would be exploring the decision making process behind choosing which sports fans tweets, texts and calls make it "on air." This issue of moderation is considered in the next section.

\section{New Media Technology and Sport: Controlling the Content}

This part of the essay will identify how the initial position of mainstream media organizations was typically one of hostility in seeking to protect their product; this position soon shifted when it was seen that new media technology could create multiple opportunities to market sport, especially to the younger generation as future audiences. The fundamental logic of capitalism demands that everything is owned and commodified with strict controls over property rights. With more sports now available via new media, mobile (handheld) and online broadcast rights are now the subject of new contracts between media organizations and sports organizations. While many English football clubs have developed their own websites and online television stations, Hutchins and Rowe (2009) identify that the key commodity in the media sport content economy remains the moving audiovisual (especially live) image.

The broadcast rights to live events are protected by intellectual property rights, trademarks and copyright. Currently, most "live rights" are sold by the rights holder (e.g., IOC, FIFA) on a platform neutral bias, that is mobile, Internet and television rights are all sold together in the same package (Wilson, 2009). In European football there is an emerging debate over the advantages (and disadvantages) for individual teams, fans and the sport as a whole in selling live rights on an individual club basis (for example, Spain's Real Madrid and Barcelona) as opposed to "joint selling" (e.g., the English Premier League). Those who are against individual selling see the growth of payper-view channels as creating a situation in which the sport becomes increasingly inaccessible to a growing number of fans. There is also concern over live blogging and live streaming of sports events (and links with "ambush marketing") and their potential to damage existing relationships (i.e., 
sponsorship deals) with "official partners" (see Birmingham \& David, 2011, for how the music industry has responded to new media technology).

One of the biggest challenges faced by right holders is combating Internet piracy and securing online copyright. As Lessig (2009) has noted, laws concerning Intellectual Property (IP) were drawn up in a very different period and are ill-suited in an era when cutting, pasting and linking have become allpervasive. The need to erect barriers (e.g., pay-walls) and create scarcity has become increasingly important for all corporations, including sporting and media, to protect existing and generate new profits. One example of the challenges being created by new media technology was evident during the 2012 Olympics when the U.S. networks delayed showing live action (Williams, 2012). Despite some high-profile incidents (Sabbagh, 2011), sports governing bodies and media corporations are responding with ever-tighter legal contracts to control access to their particular commodity, including UEFA's role in the expanding, lucrative markets of China and India (Wilson, 2012; see also Burton \& Chadwick, 2009; LOCOG, 2011; Magnay, 2011; Portlock \& Rose, 2009).

Much has been made of the opportunities created by new media technology, in particular its ability to create and facilitate dialogue between the owners, producers and the consumers, at the same time as offering the potential for individual emancipation and empowerment. However, the dominant mode of production in the telecom and media industries has seen increased complicity between themselves and state governments to oppose democratic activity in favour of preserving the existing neoliberal capitalist structures." In the sporting sphere, Jhally $(1989$, p. 89) identified the privileged role enjoyed by mainstream media structures in encoding sporting texts, and how the process of accumulation and legitimization meant that alternative views or controversial framings of sporting events were rarely heard and that within this commodity relationship too often the media producers provide highly selective reformulations or reinterpretations of sporting events in ways that seek legitimation for dominant understandings of militarism, nationalism, competition, authority, and consumption.

Bellamy and McChesney (2011) claim that despite (or because of?) new media we are now in a "golden age" of propaganda (see also Boyle \& Haynes, 2010; Hutchins \& Rowe 2009; Phillips \& Hutchins, 2003). What has often been neglected in the uncritical promotion of the openness and democratization engendered by new media technologies is the role of the moderator. Most websites have a moderator (or teams of moderators) who monitor the online conversation and submissions to their site. Some sites do show where a comment has been removed, but many sites do not give an indication of how many contributions were made, nor how many were rejected. This creates a potential for dissenting voices to be excluded from certain online conversations, although the common response to this that we all now have the freedom and option to set up our own website and "have our say."iii So while new media does allow sports fans to bypass the mainstream media and set up their own blog or e-zine, as a former CEO of Google noted "the average blog has one reader: the blogger" (quoted in Leonard, 2006). As Dart (2009) found in his research during the 2008 FIFA World Cup finals, the mainstream media used their cross platforms and partner 
corporations to successfully colonize and dominate football fans' online activity. One conclusion one might draw is that once the florid rhetoric of self-organization, openness and a bottom-up participatory, democratizing culture is subject to scrutiny, the reality of "new" media is one of an overarching, top-down corporate controlled structure (see also Gallagher \& Syal, 2011; Lehmann, 2011).

\section{New Media-Old Issues?}

As noted earlier, one needs to avoid operating an artificial dichotomy between old and new media. It was also noted that new media technologies are developed within wider economic and social relations. Given this, it is perhaps unsurprising that early research on professional sport online reflects wider social relations and mores. Multiple examples exist, but among the most high profile sports-related incidents was the British university student who tweeted racist comments about Bolton footballer, Fabrice Muamba, who collapsed during a game against Tottenham (Morris, 2012). Millward's (2008a) study on online fan forums and e-zines suggested that the Internet offered an extension of the football grounds as a venue to engage in traditional fandom rivalry, and which included racism (specifically Islamophobia) and homophobia. During the preparation of this essay, Black British football players and commentators were targeted online by racists when they spoke out against Liverpool FC's decision to support a player found guilty of using racist language against a fellow professional (Lawton, 2011; see also Leonard \& King, 2011; Millward, 2008b). Research by Millward (2012) on attempts by fans of Liverpool FC to influence the ownership of their club complements research by Rowe, Ruddock, and Hutchins' (2010), on Ebbsfleet United new media experiment, both of which highlight the unrealistic expectation placed on new media technologies.

The ideological values promoted in society and in the mainstream media can also be found in the online media. Clavio and Eagelman (2011) suggest that sports blogs have become a viable alternative and competitor to the mainstream sports websites, even though six of the ten biggest blogs sites were owned and operated by traditional sports media corporations. They found that the majority of images they coded featured males as the prominent subject with a lack of female sports coverage (this despite the virtual absence of spatial constraints online). When women did feature they were significantly more likely to be presented in a sexual nature and were primarily framed as cheerleaders, dancers, or models with little sport-specific content or context. This reproduction online of conventional media mores regarding female in sport is as unacceptable as it is unsurprising. What these initial studies show is that new media are reproducing many of the issues found in mainstream media and society. The question is "why would we expect people's online behaviour and attitudes to become different, let alone progressive?" Perhaps the most vexed question that has arisen with the growth of new media technologies is how much freedom should there be to say what you want online, and who, if anyone, should "police" the internet (Monbiot, 2008).

\section{Athletes and New Media Technology}


Having briefly outlined how sports fans have begun to engage with new media technology, consideration is now given to how athletes, sports teams and governing are responding. As noted, new media technologies are seen as allowing fans unprecedented insight and access into the lives of their favourite player/athlete. One, as yet unresolved, tension is the desire of sports teams and organizations to control not only their product (most importantly, the live event), but also the more ephemeral "wraparound" content and ensure they extract as much profit from their product. Unlike sports fans, it is individual athletes who are well-placed to monetize new media technology by using it as an additional platform in the promotion of themselves and their sport. For athletes, their agents and sponsors, image rights (personality rights in the USA) have increasingly become a lucrative source of income (Andrews \& Jackson, 2001; Cashmore, 2002; Haynes, 2008; Rojek, 2001). However, for Hutchins and Rowe (2009) the legal recognition of image rights and "property in personality" is a commodification too far (see also Boyle \& Haynes, 2010). With athletes becoming media content platforms and new technology seen as allowing authentic relationships to be developed with their fans, as Rojek (2006) suggests this can inform the development of fantasy relationships between the fan and the sports star. Relatedly, Rahman and Lockwood's (2011) research illustrates the contradictory discourse between authenticity and the commercialization found within the modern Olympics. Given the corporate and media funds needed to stage the Olympics, Rahman and Lockwood suggest the representation of athletes occurs within, and draws upon, a celebrity and commodity culture that primarily serves the accumulation strategies of corporations.

Showing how athletes are commodified (exploited?) by the corporations, they question the supposed ancient ethos of "taking part" and conclude that commercialization is inevitable because of a dependency on wider corporate commercialized leisure, the centrality of the entertainment and media industries and commodity finance. There is a growing trend among athletes to use social media to bypass the mainstream media and "spin" their version of events directly to the fans, without having to rely on a potential unsympathetic third-party mediator (Independent, 2009). For an athlete, having a strong presence across social media platforms also strengthens their brand and creates greater opportunities for personal endorsement and their marketability to sponsors. ${ }^{\text {iv }}$ However, in June 2012, British footballers Wayne Rooney and Jack Wiltshire were sanctioned by the U.K.'s Advertising Standards Authority for using their tweets to advertise a Nike campaign (Sweney, 2012). Shortly after this the English Premier League (EPL) issued guidelines on the use of social media aimed, they said, at protecting the players, their clubs and the EPL's product. As its Chief Executive claimed Social media is doing a good job of allowing fans to feel closer to the players. There is a more human side now to some of the players and the public can communicate more directly with them. (Premier League, 2012)

At the same time, the growth of 24-hour rolling news networks and the rise of social media (and Twitter in particular), have meant that athletes' agents and sports organizations have to engage in constant impression management (or crisis/reputation) management, such as the Michael Phelps' "bong-pipe incident" (Walsh \& McAllister- Spooner, 2011; see also Gibson, 2010). While a review of the most popular sports websites shows they are dominated by the traditional/mainstream media corporations (e.g., ESPN, CBS, NBC, Sports Illustrated, and Fox), and official websites (e.g., NBA. com; 
NFL.com; FIFA.com, and WWE.com), one can also find websites that offer alternatives to the $\mathrm{PR} /$ charm-offensives conducted by sports agents, clubs, and organizations. Websites such as Deadspin, Bleacher Report, Yardbarker, and Caughtoffside depend on rumour, gossip, and "other things you won't find on any other official sportsoriented site" (Deadspin.com). As such, these sites act as disruptive, dissenting voices, due in part to sitting outside the mainstream and not having to worry about upsetting sponsors or losing any official access rights. Sports agents, organizations and sponsors are concerned when negative incidents are reported on these sites but become increasingly concerned if/when such stories are picked up by the mainstream (old) media. The relationship between these enfant terrible websites and the mainstream media and sports team/organizations is a potentially interesting area of study, especially given the churnalistic tendencies (Harcup, 2008) that can be found across large swathes of the mainstream sports media. Contributing to this situation is how new media are testing individual nation state's privacy laws with Manchester United's Ryan Giggs, celebrities and politicians finding it increasingly difficult to conceal their identity (Daily Telegraph, 2012; Deadspin, 2011).

As noted previously, one of the key questions asked of new media technologies is "how to generate a profit" and how this has been partly addressed through data mining and advertising. Informing this issue of profit-generation is the testing issue of ownership of social media accounts, and at what stage sports fans become a commodity/ property. The social networking, or microblogging service, of Twitter accords "value" to the lists of followers that individuals (here, athletes) have developed. Athletes such as Shaquille O'Neal, Kaka, and Ronaldo have millions of followers, and their list of followers becoming highly valuable commercial commodities. ${ }^{v}$ With information now seen as a synonymous with power in the networked society (Castells, 2000/1996), athletes are centrally placed to disseminate directly, on their own terms, to their own fan base. Currently going through the law courts is a case based on trying to ascertain "who owns these lists?" and identifying the commercial value of followers acquired in a business context. One early opinion is that if the organization is included as part of a suffix (as a hypothetical example Beckham@LAGalaxy), it is potentially more likely that "the list" will belong to LA Galaxy (Biggs, 2011; Mitrano, 2012). What is certain is that sports teams and organizations will, with their lawyers, become more adept at devising policies that explicitly identify who owns these accounts (Biggs, 2011). Research which explores the content of an athlete's tweets and their Facebook pages, and identifies the relationship between their content (e.g., tweets), sponsorship deals and image management would be a useful contribution in discussion on the nature of contemporary sporting celebrity.

\section{Sports Teams and Organizations and New Media Technology}

While individual athletes (and their agents) have taken advantage of new media technology to maximize their profile and advertising revenue streams (Oates, 2009), sports governing bodies were less assured in their initial encounters with new media technology. Hutchins and Rowe (2009) identify how blogging during the 2007 Pan- American Games was initially banned, but also how governing bodies soon realized that this was not a practical option. Research by Marshall, Walker and Russo (2010) during the 2008 Olympics Games identified the rise of the amateur (i.e., a nonaccredited individual), equipped with a mobile/cell phone to have their say, but found that the 
multiplicity of media platforms typically stayed under the control of mainstream media organizations which had paid for exclusive rights to the event. Hutchins and Mikosza (2010) found that blogging during the Beijing 2008 Olympics was heavily restricted, with this unofficial "ban" quickly revised to allow individuals to blog, albeit with heavy restrictions on what they could write about. Their conclusion, that the IOC adopted a Janus-faced approach by simultaneously accepting additional avenues to promote the Olympic brand while seeking to maintain control over Olympic related media in online environments, can be seen as emblematic of sports governing bodies attitude to new media technology. While new media are challenging the popularity and profits of traditional, mainstream media organizations, at issue is the extent to which control is being asserted this "old" media. While audiences search for ways of connecting to global sporting events, which can circumvent existing structures, the above studies echo that found by Dart (2009) who demonstrated how during the 2006 FIFA World Cup Finals the existing mainstream media, supported by large corporations, adapted and exploited the opportunities offered by new media technologies to supplement their exclusive rights to cover the live event. One can conclude from this first wave of research that a convergence of powerful forces of national governments, transnational media corporations and sports organizations (e.g., IOC and FIFA), national and international laws and treatise such as copyright (designed to protect the interests of capital), are all coalescing to shape the emergent form(s) of sports coverage. What this first tranche of new media research also illustrates is a shift in attitude and behaviour. Fearful of its potential to destabilize the long-standing, mutually beneficial relationship between the mainstream media, sports governing bodies and sponsors (Jhally's "golden triangle"), they have each sought to reposition themselves. The immense popularity of new media technology and its rapid entry into the mainstream, the logic of the neoliberal marketplace (i.e., political economy) meant it could no longer be ignored or banned (Bloom, 2012; Daily Mail, 2011; Khan, 2010; NZ Herald, 2011). The leverage it offered, coupled to the certainty that if they did not adopt it someone else would, has led to its embrace. One can see this in the popularity of the USA Olympic Team's 2012 Facebook campaign and Manchester United FC's presence on Facebook. One might see this as a worthy attempt by sports bodies to "bring athletes closer to their fans" or alternatively, as an attempt to capture market share (in terms of delivering audiences to sponsors).

Rowe et al. (2010) suggest that in the post hegemonic broadcast age developments in new media require a shift in thinking away from the traditional conception of professional sport and media towards recognizing forms of professional sport as media in networked digital media environments; however, it is not clear what, if anything, has significantly changed in the fundamental nature in the production of professional sport, especially given how the dominant structures remain untouched. Noting the availability and ease with which digital media content can be distributed and duplicated, Hutchins and Mikosza (2010) suggest that the unpredictability of the Internet is creating opportunities to symbolically undermine the economic and political power wielded by governments and international sports organizations. However, they themselves conclude that such activities in the sports world are unlikely to represent a substantive strike against the powerful governments, and caution that social media are often being accorded vastly more symbolic praise than is warranted. 


\section{Conclusion}

The way sport is marketed and how fans access and interact with each other and with their sport has changed - of this there is little doubt. Sport is fundamentally a social experience with new media technology creating greater connections between fans, and between fans and their teams and athletes. However, some unanswered questions remain, including (a) How deep-seated and democratic are the relationship engendered by new media; (b) Why are sports teams, organization and media corporation so proactive in promoting its usage? (c) What informs the decision-making process in deciding which fan's contribution makes it on-air/on-line? (d) Has new media technology substantially changed the fundamental structures within professional sports which are based on commodification and the profit motive? When one employs the critique of neo-Marxist political economy to scratch the surface of new media rhetoric one soon realizes that most of the claims made are either extremely selective or wholly vacuous.

Initially, the emergence of new media technologies presents researchers with a paradox. The field of sports media is seemingly highly fluid with new media technology, at least in the popular imagination (and for the Chief Executive of the EPL), allowing one to bypass the old structures and let interested parties (i.e., fans) engage in more immediate, democratic, and authentic interactions ("conversations") with their favourite players. However, the logical expression of the neoliberal market economy is manifesting itself in athletes, sports clubs, sports organizations and sports related corporations rapid adoption and exploitation of new media technology and the increased commodification of the sporting experience. What the first wave of research on sport and new media indicates-sometimes explicitly, sometimes implicit-is the overriding, continuing importance of acknowledging political economy. The wider contexts in which sport and new media operate have a tendency to be forgotten as people get caught up in the "bright lights" displayed on their shiny new gadgets. While sensitive to the changes that have taken place one should be careful not to exaggerate the likelihood of the virtual content, including sports, as being significantly different from what is found in the "real world." Those who claim there have been far-reaching, profound changes (i.e., a media/communications revolution) are probably overstating their case. In the world of professional sport the basic product(s) remains the same, with the main change taking place in how this product (i.e., the live event) is accessed and the mediated interactions that surround that product. As Blackshaw (2006) has noted, media and sponsors are increasingly using major sporting events as both a catalyst and context for developing online conversations. What is emerging is how well practiced they have become in using consumer generated media to reinvent how sponsored content wraps around, and amplifies, the sports experience. The challenge for sports teams, organizations, media companies and sponsors will be in creating and retaining audiences in a pluralist media world and engaging in sustained conversations with the sports fan. With young people in particular expecting personalized and instant access, it will be interesting to see how sports producers (be this athletes, clubs, federations and host cities) and media organizations use new media technology as leverage, that is, as a customer service tool in integrated marketing campaigns to attract and retain the interest of sports fans (and by default, sponsors). 
There remains a need to show cognizance of the multiplicity of forces at play and ground future sports research in an appropriate, real-world, context. An examination of contemporary professional sport clearly demonstrates the need to employ a materialist political economy analysis to allow for the historicity of capitalism to be fully contextualized and properly identify where power, control and real interests lay. As Phillips and Hutchins (2003) have noted, the concept of political economy allows for a greater understanding of power relationship under capitalism and generates the fundamental question of "who owns and controls the means and relations of economic production and political power?" One can suggest that the original sport/media complex identified by Jhally (1984) has become ever more concentrated, with Schiller's (1973, p. 175) question still apposite: "for whose benefit and under whose control will it be implemented?"

The way we consume sport, and the extent to which we become part of sporting events will continue to evolve in unanticipated directions. Developments in new media technologies will present a series of paradoxes to sports fans, athletes, sports and media organizations, sponsors/advertisers and, not least, to the sports sociologist. Underpinning these paradoxes will be the dualism of (a) an explicit process of capitalist accumulation and profit maximization in an increasingly closed, proprietary, monopolistic digital market (Bellamy \& McChesney, 2011); and (b) an incredible array of opportunities for connections between sports fans, players and sports organizations. Utilizing the concept of political economy to review the first wave research on professional sport and new media suggests that emerging media technologies do not present a threat to the conventions of the neoliberal marketplace, but rather adds to the commodification of professional sport and helps ensure it remains wholly capitalist in nature. 


\section{References}

Andreff, W. (2006). Sport and financing. In A. Andreff, \& S. Szymańsk (Eds.), Handbook on the economics of sport (pp. 271-281). Cheltenham: Elgar.

Andrews, D. L. (2001). Sport. In R. Maxwell (Ed.), Culture works: Essays on the political economy of culture (pp. 131-162). Minneapolis: University of Minnesota Press.

Andrews, D., \& Jackson, S. (2001). (Eds.). Sport stars: The cultural politics of sporting celebrity. London: Routledge.

Arthur, C., \& Kiss, J. (2009, June 11). MySpace and Bebo are running out of friends. Retrieved from http://www.guardian.co.uk/technology/2009/jun/11/myspace-bebo-social-networking

BBC (2002, December 20). Murdoch wins China state TV deal. Retrieved from http://news.bbc.co.uk/1/hi/business/2593645.stm

Beamish, R. (1982). Sport and the logic of late capitalism. In H. Cantelon, \& R. Guuneau (Eds.), Sport, culture and the modern state (pp. 141-197). Toronto: University of Toronto Press.

Bellamy, J., \& McChesney, R. (2011, March). The internet's unholy marriage to capitalism. Monthly Review, 62, 10. Retrieved from http://monthlyreview.org/2011/03/01/the-internetsunholymarriage-to-capitalism

Benkler, Y. (2006). The wealth of networks. The wealth of networks: How social production transforms markets and freedom. Retrieved from http://www.congo-education.net/wealthofnetworks/

Biggs, J. (2011). A dispute over who owns a Twitter account goes to court. New York Times. Retrieved from http://www.nytimes.com/2011/12/26/technology/lawsuit-may-determinewhoowns-a-twitter-account.html

Birmingham, J., \& David, M. (2011). Live-streaming: Will football fans continue to be more law abiding than music fans? Sport in society: Cultures, Commerce, Media, Politics, 14(1), 69-80. 
Blackshaw, P. (2006). Kicking the world cup blog ball. The ClickZ Network. Retrieved from http://www.clickz.com/showPage.html?page=3612531

Bloom, B. (2010, January, 21). Manchester United ban Twitter and Facebook. Retrieved from http://www.thesportreview.com/tsr/2010/01/manchester-united-ban-twitter-facebook/

Boyle, R., \& Haynes, R. (2000). Power play: Sport, the media and popular culture. Harlow, England: Pearson.

Boyle, R., \& Haynes, R. (2010). New media sport. Sport in Society/Culture, sport, Society, 5(3), 96114.

Branigan, T. (2010, 13 January) Google to end censorship in China over cyber attacks. Guardian. Retrieved from http://www.guardian.co.uk/technology/2010/jan/12/google-chinaends-censorship

Brohm, J-M. (1989). Sport. A prison of measured time. (Ian Fraser, Trans.). London: Pluto Press.

Burton, N., \& Chadwick, S. (2009). Ambush marketing in sport: An analysis of sponsorship protection means and counter-ambush measures. Journal of Sponsorship, 2, 303-315.

Carr, N. (2011, August 19). Digital sharecropping (rerelease). Retrieved from http://www.roughtype.com/archives/2011/08/digital_sharecr.php

Cashmore, E. (2002). Beckham. Cambridge: Polity

Castells, M. (2000/1996). The rise of the networked society. Oxford: Blackwell.

Castells, M. (2001). The Internet galaxy. Reflections on the Internet, business and society. Oxford:

Oxford University Press. 
Clavio, G., \& Eagleman, A. (2011). Gender and sexually suggestive images in sports blogs. Journal of Sport Management, 7, 295-304.

Cohen, N. (2008). The valorisation of surveillance: Towards political economy of Facebook. Democratic Communiqué, 22(1), 5-21.

Crawford, G. (2004). Consuming sport: Fans, sport and culture. London: Routledge.

Dart, J. (2009). Blogging the 2006 FIFA world cup finals. Sociology of Sport Journal, 26(1), 107-126.

Daily Mail (2011, February 16). It's NOT good to talk! ICC ban mobile phones from dressing rooms in corruption clampdown. Retrieved from http://www.dailymail.co.uk/sport/cricket/ article1357521/ICC-ban-mobile-phones-dressing-rooms.html\#ixzz1jGHrej7w

Daily Telegraph (2012, Feb 21). Ryan Giggs finally gives up anonymity over Imogen Thomas "affair." Daily Telegraph. Retrieved from http://www.telegraph.co.uk/sport/football/9095826/ Ryan-Giggsfinally-gives-up-anonymity-over-Imogen-Thomas-affair.html

Deadspin (2011, May 20). Totally anonymous soccer player sues Twitter for saying Ryan Giggs had an affair. Retrieved from http://deadspin.com/5804120/totally-anonymous-soccerplayer- sues-twitterfor-saying-ryan-giggs-had-an-affair

Epstein, D., Nisbet, E., \& Gillespie, T. (2011). Who's responsible for the digital divide? Public perceptions and policy implications. Information Society, 27(2), 92-104.

Forbes (2012). Media companies dump sport teams. Forbes. Retrieved from http://video.forbes.com/fvn/sportsmoney/media-companies-dump-sports-teams

Forrester, J. (2011). Tackling the digital divide. Retrieved from http://digital.cabinetoffice.gov. uk/2011/12/02/tackling-the-digital-divide/

Fuchs, C. (2008). The Internet and society. Social theory in the information age. Abingdon: Routledge. 
Fuchs, C. (2011). A contribution to the critique of the political economy of Google. Fast Capitalism, 8(1). Retrieved from http://www.uta.edu/huma/agger/fastcapitalism/8_1/fuchs8_1.html

Gallagher, R., \& Syal, R. (2011, October 30). Met Police using surveillance system to monitor mobile phones. Retrieved from http://www.guardian.co.uk/uk/2011/oct/30/metropolitanpolice-mobilephone-surveillance

Gibson, O. (2010, September 12).There's trouble @Twitter. Observer. Retrieved from http://www.guardian.co.uk/sport/2010/sep/12/twitter-owen-gibson

Giulianotti, R. (2002). Supporters, followers, fans and flaneurs: A taxonomy of spectator identities in football. Journal of Sport and Social Issues, 26(1), 25-46.

Giulianotti, R. (2005). Sports spectators and the social consequences of commodification. Journal of Sport and Social Issues, 29, 386-410.

Gruneau, R., \& Whitson, D. (2001). Upmarket continentalism: Major league sport, promotional culture, and corporate integration. In V. Mosco \& D. Schiller (Eds.), Continental order? Integrating North America for cybercapitalism (pp. 235-264). Lanham, MD: Rowman \&Littlefield.

Guardian (2011a). Wikileaks. Retrieved from http://www.guardian.co.uk/media/wikileaks

Harcup, T. (2008, February 18). Reporters need to ask what they're not being told. Press Gazette. Retrieved from http://www.pressgazette.co.uk/story. asp?sectioncode $=1 \&$ storycode $=40268$

Hargreaves, J. (1982). Sport, culture, and ideology. In J. Hargreaves (Ed.), Sport, culture and ideology (pp. 30-61). London: Routledge.

Harvey, D. (2005). A brief history of neo-liberalism. Oxford: Open University Press 
Haynes, R. (2008). Footballers' image rights in the new media age. European Sport Management Quarterly, 7, 361-374.

Hirst, M., \& Harrison, J. (2011). Communication and new media. From Broadcast to Narrowcast. Oxford: Oxford University Press.

Hoberman, J. (1984). Sport and political ideology. Austin: University of Texas Press.

Hoch, P. (1972). Rip off the big game. The exploitation of sports by the power elite. New York: Doubleday.

Hughson, J., \& Free, M. (2006) Paul Willis. Cultural commodities and collective sport fandom. Sociology of Sport Journal, 23, 72-85.

Hutchins, B., \& Mikosza, J. (2010). The Web 2.0 Olympics. Athlete blogging, social networking and policy contradiction at the 2008 Beijing Games. Convergence: The International Journal of Research into New Media Technologies, 16, 279-297.

Hutchins, B., \& Rowe, D. (2009). From broadcast scarcity to digital plenitude. The changing dynamics of the media sport content economy. Television and New Media, 10, 354-370.

Independent (2009, March 30). Athletes turn to Twitter for their own spin. Retrieved from http://www.independent.co.uk/life-style/gadgets-and-tech/news/athletes-turn-to-twitter-fortheirown-spin-1657482.html

Jhally, S. (1984). The spectacle of accumulation: Material and cultural factors in the evolution of the sports/media complex. Insurgent Sociologist, 12, 43-57.

Jhally, S. (1989). The spectacle of accumulation: Essays in culture, media, \& politics. New York: Lang.

Jones, J. (2011). Social media and social movements. International Socialism, 130. Retrieved from http://www.isj.org.uk/?id=722 
Khan, U. (2010, January 20). Manchester United bans players from Twitter. Retrieved from http://www.telegraph.co.uk/technology/news/7035818/Manchester-United-bans-playersfromTwitter.html

Knight, G., \& Greenberg, J. (2002). Promotionalism and subpolitics: Nike and its labor critics. Management Communication Quarterly, 15, 541-570.

Law, A., Harvey, J., \& Kemp, S (2002). The global sport mass media oligopoly. International Review for the Sociology of Sport, 37, 279-302.

Lawton, J. (2011, December 24). Football's race row intensifies as Black pundits are targeted online. Retrieved from http://www.independent.co.uk/sport/football/news-and-comment/footballs-racerow-intensifies-as-black-pundits-are-targeted-online-6281272.html

Lehmann, C. (2011, March 2). An accelerated grimace: On cyber-utopianism. Retrieved from http://www.thenation.com/article/158974/accelerated-grimace-cyber-utopianism

Lenskyj, H. (2000). Inside the Olympic industry: Power, politics, and activism: Albany: SUNY Press.

Lenskyj, H. (2002). The best Olympics ever?: Social impacts of Sydney 2000. Albany: SUNY Press.

Leonard, D., \& King, C. R. (2011). Lack of Black opps: Kobe Bryant and the difficult path of redemption Journal of Sport and Social Issues, 35(2), 209-222.

Leonard, T. (2006, November 23). Blogging all over the world. Retrieved from http://www.telegraph.co.uk/arts/main.jhtml?xml=/arts/2006/10/17/bablog17.xml

Lessig, L. (2009). Remix: Making art and commerce thrive. Retrieved from http://creativecommons.org/weblog/entry/14329 
Levy, A. (2011). Facebook valuation tops Amazon.com, trailing only Google on web.

Bloomberg.Retrieved from http://www.bloomberg.com/news/2011-01-28/facebook-s-82-9-

billionvaluation-tops-amazon-com-update1-.html

Lipsky, B. (1979). Political implications of sports team symbolism. Politics and Society, 9, 61-88.

LOCOG 2012 (2011). Brand protection. Retrieved from

http://www.london2012.com/documents/brand-guidelines/guidelines-for-non-commercial-use.pdf

Magnay, J. (2011, March 7). London 2012 Olympics: Government unveils plans to ban ambush marketing and bolster games security. Retrieved from

http://www.telegraph.co.uk/sport/olympics/8367354/London-2012-Olympics-Government-unveilsplans-to-ban-ambushmarketing-and-bolster-Games-security.html

Maguire, J. (1999). Global sport: Identities, societies, civilizations. Cambridge: Polity Press.

Marshall, D. P., Walker, B., \& Russo, N. (2010). Mediating the Olympics. Convergence. The international journal of research into new media technologies, 16, 263-278.

McDonald, M. (2006). Thinking through power in sports and sport media scholarship. In A. Raney \& J. Bryant (Eds.), Handbook of sports and media (pp. 501-522). US: Lawrence Erlbaum.

Millward, P. (2008a). The rebirth of the football fanzine. Using e-zines as data source. Journal of Sport and Social Issues, 32, 299-310.

Millward, P. (2008b). Rivalries and racisms: "Closed" and "open" Islamophobic dispositions amongst football supporters. Sociological Research Online, 13(6), 5. Retrieved from http://www.socresonline.org.uk/13/6/5.html

Millward, P. (2012). Reclaiming the kop? Analysing Liverpool supporters' twenty-first century mobilizations. Sociology [published online 18 April 2012]. doi:10.1177/0038038511425557 
Mitrano, T. (2012). Who owns a Twitter account? Inside higher ed. Retrieved from http://www.insidehighered.com/blogs/who-owns-twitter-account

Monbiot, G. (2008, September 17). How can the rich still be buying our silence with this 13thcentury law? Guardian. Retrieved from http://www.guardian.co.uk/commentisfree/2008/sep/17/matthiasrath.medialaw

Morris, S. (2012, May 22). Student who mocked Fabrice Muamba on Twitter "massively sorry." Guardian. Retrieved from http://www.guardian.co.uk/uk/2012/may/22/muambatwitter-abusestudent-sorry?utm_source=twitterfeed\&utm_medium=twitter

Nash, R. (2000). Contestation in modern English professional football. The independent supporters association movement. International Review for the Sociology of Sport, 35, 465-486.

Naughton, J. (2012, January 8). Sopa and Pipa: Don't let big business break the Internet.Retrieved from http://www.guardian.co.uk/technology/2012/jan/08/online-piracy-challengesopa-pipa

Nylund, D. (2007). Beer, babes, and balls: Masculinity and Sports Talk Radio. Albany, NY: SUNY Press.

NZ Herald (2011, October 27). All Blacks all Twitter after Rugby World Cup ban lifted. Retrieved from http://www.nzherald.co.nz/all-blacks/news/article.cfm?c_id=116\&objectid=10761944

Oates, T. (2009). New media and the repackaging of NFL Fandom. Sociology of Sport Journal, 26, 3149.

Parry, M., \& Malcolm, D. (2004) England's Barmy Army: Commercialism, masculinity and nationalism. International Review for the Sociology of Sport, 39(1), 75-94.

Phillips, M., \& Hutchins, B. (2003). Losing control of the ball: The political economy of football and the media in Australia. Journal of Sport and Social Issues, 27, 215-232. 
Portlock, A., \& Rose, S. (2009). Effects of ambush marketing: UK consumer brand recall and attitudes to official sponsors and non-sponsors associated with the FIFA World Cup 2006. International Journal of Sports Marketing \& Sponsorship, 10, 271-286.

Premier League (2012, July 24). Premier League issues club guidelines on social media. Retrieved from http://www.premierleague.com/en-gb/news/news/premier-league-issuesclub-guidelines-onsocial-media.html

Rahman, M., \& Lockwood, S. (2011). How to "use your Olympian": The paradox of athletic authenticity and commercialization in the contemporary Olympic games. Sociology, 45, 815-829.

Rigauer, B. (1994). Leftist theories of sport: A critique and reconstruction. Illinois: University of Illinois Press.

Rojek, C. (2001). Celebrity. London: Reaktion.

Rojek, C. (2006). Sports celebrity and the civilizing process. Sport in Society, 9, 674-690.

Rowe, D. (2004). Sport, culture and the media: The unholy Trinity (2nd ed.). Buckingham: OU Press.

Rowe, D., Ruddock, A., \& Hutchins, B. (2010). Cultures of complaint: Online fan message boards and networked digital media sport communities. Convergence: The International Journal of Research into New Media Technologies, 16, 298-315.

Sabbagh, D. (2011, October 4). Analysis: Pub landlady v Premier League. Retrieved from http://www.guardian.co.uk/media/2011/oct/04/analysis-pub-premier-league-rights

Sage, G. (1999). Justice do it! The Nike transnational advocacy network: Organization, collective actions, and outcomes. Sociology of Sport Journal, 16, 206-235.

Schiller, D. (2007). How to think about information. Urbana: University of Illinois. 
Schiller, H. (1973). The mind managers. Boston: Beacon.

Schiller, H. (1983). The communications revolution: Who benefits? Media Development, 30(4), 1820.

Slack, T., Silk., M., \& Hong, F. (2005). Cultural contradictions/contradicting culture: Transnational corporations and the penetration of the Chinese market. In Silk, M., Andrews, D., \& C. Cole (Eds.) Sport and corporate nationalisms (pp. 253-274). Oxford: Berg.

Stoddart, B. (2004). Convergence: Sport on the information super highway. In D. Rowe (Ed.), Critical readings: Sport, culture and the media (pp. 328-339). Maidenhead: Open University Press.

Sweney, M. (2012, June 20). Nike becomes first UK company to have Twitter campaign banned. Guardian Online. Retrieved from http://www.guardian.co.uk/media/2012/jun/20/nike-twittercampaign-banned

Thompson, B. (2007, October 17). Daily reality of net censorship. Retrieved from http://news.bbc.co.uk/1/hi/technology/7047592.stm

Toffler, A. (1980). The third wave. London: Pan Books.

Walsh, J., \& McAllister-Spooner, S. (2011). Analysis of the image repair discourse in the Michael Phelps controversy. Public Relations Review, 37(2), 157-162.

Wann, D., Melnick, M., Russell, G., \& Pease, D. (2001). Sport fan: The psychology and social impact of spectators. London: Routledge.

Wenner, L. (Ed.). (1998). Media sport. New York: Routledge.

Whannel, G. (1992). Fields of vision: Television sport and cultural transformation. London: Routledge. 
Whannel, G. (2008). Culture, politics and sport: Blowing the whistle, revisited. London: Routledge

Whitson, D. (1998). Circuits of promotion: Media, marketing and the globalization of sport. In L. Wenner (Ed.), Media sport (pp. 57-72). New York: Routledge.

Williams, M. (2012, August 2). NBC concedes Olympics criticism is fair as network makes coverage changes. Guardian Online. Retrieved from http://www.guardian.co.uk/media/2012/ aug/02/nbccriticism-olympics-coverage-changes

Williams, J. (2007). Rethinking sports fandom: The case of European soccer. Leisure Studies, 26(2), 127-146.

Wilson, B. (2009). Can sport still net winning TV deals? Retrieved from http://news.bbc.co.uk/1/hi/business/8026393.stm

Wilson, B. (2012). UEFA aims to make international football a TV turn-on. Retrieved from http://www.bbc.co.uk/news/business-17536407

Wilson, B., \& White, P. (2002). Revive the pride: Social process, political economy and a fanbased grassroots movement. Sociology of Sport Journal, 19(2), 119-148.

\footnotetext{
' See the spectacular financial collapse of Bebo and Myspace (Arthur \& Kiss, 2009).
}

ii Outside of professional sport, one can point to the four year period of self-censorship by Google in China (Branigan, 2010), and News Corporation's agreement with the Chinese state regarding Star TV (BBC, 2002; Slack, Silk, \& Hong, 2005; see also Thompson, 2007). More recently, during the "Arab uprisings" in 2010 and 2011 major telecom corporations, responding to requests from national governments, closed down national networks (Jones, 2011). AT\&T have illegally monitored communication of its customers on behalf of the National Security Agency (Bellamy \& McChesney, 2011), while PayPal, Amazon, eBay and others have cooperated with the US government to disrupt the wikileaks website (Guardian, 2011a). In early 2012, the U.S. Congress was considering legislation (sopa and pipa) which would allow them to block sites accused of copyright infringement at domain level (Naughton, 2012). 
iii Notwithstanding the issue of a "digital divide" (see Epstein, Nisbet, \& Gillespie, 2011; Forrester, 2011).

iv Given the changing popularity of sports stars, a number of websites track trends in social media, for example see http://pagedata.insidefacebook.com or http://sports.yahoo.com/blogs/ post/Thetop-10-most-popular-athletes-on-Twitter?urn=top-328593

${ }^{\vee}$ Given the changing trends on Twitter, the website http://sports.yahoo.com/blogs/post/Thetop- 10most-popular-athletes-on-Twitter?urn=top-328593 tracks the current favorites and trends on this particular media platform. 